CASE REPORT

\title{
An ACE diagnosis
}

\author{
Omar Nasher, Anindya Gupta
}

Department of Rheumatology, Nottingham University Hospitals NHS Trust-Queen's Medical Centre, Nottingham, UK

\section{Correspondence to} Dr Omar Nasher, omar.nasher@nhs.net
To cite: Nasher 0 Gupta A. BMJ Case Rep Published online: [please include Day Month Year] doi:10.1136/bcr-2012 008185

\section{SUMMARY}

Gaucher's disease is not commonly considered in the differential diagnosis of adult patients with hepatosplenomegaly and increased serum ACE. A 19-year-old girl presented with recurrent epigastric and left hypochondrial pain over a period of 9 years, associated with episodes of nausea and diarrhoea. She was extensively investigated and found to have splenomegaly and raised serum ACE. A screen for haematological disorders was negative. She reported an insect bite during an overseas holiday preceding her symptoms. She was therefore also screened for infectious causes of hepatosplenomegaly but without success. Later on in life, she reported joint pain and discomfort. Sarcoidosis was thought to be the putative cause on more than one occasion. However, the presence of splenomegaly and her relatively young age, led the rheumatologist to the correct diagnosis.

\section{BACKGROUND}

Gaucher's disease is the most common inherited lysosomal storage disease, with an incidence of between 1 in 40000 and 1 in 60000 live-births. ${ }^{1}$ Approximately 250 patients have this condition in England and Wales. ${ }^{1}$ It often manifests with nonspecific clinical features that can sometimes mimic other more common disorders. A high index of suspicion is necessary in order to make the definitive diagnosis and promptly start enzyme replacement treatment to improve the quality of life of these patients.

\section{CASE PRESENTATION}

A 19-year-old female patient first presented to the paediatric surgery clinic at 10 years of age in November 2004 with recurrent epigastric and left hypochondrial pain occurring every 3 months and lasting 3-5 days, associated with episodes of nausea and diarrhoea. She also reported occasional nose bleeds. At birth, she had aspiration of meconium but had been otherwise well until the age of 10 . Her father had been diagnosed with ulcerative colitis and her maternal aunt had coeliac disease. Initial ultrasound scan of the abdomen showed a mildly enlarged spleen $(15 \mathrm{~cm})$ and a right ovarian follicle. In addition, given her family history, she underwent colonoscopy with biopsy which was inconclusive.

A repeat ultrasound scan in 2009 showed persistent splenomegaly. In view of her splenomegaly, she was referred to the haematology clinic in January 2010 where she was screened for hereditary spherocytosis, autoimmune haemolytic anaemia, rheumatoid arthritis, sarcoidosis, porphyria and haemoglobinopathies. Her investigations showed normal haemoglobin, lactate dehydrogenase and reticulocyte count, negative Coomb's test, mild thrombocytopaenia in keeping with the splenomegaly and a normal blood film. Chest x-ray was also normal. Moreover, erythrocyte sedimentation rate and C-reactive protein were both within the normal range. Serum ACE was elevated to $207 \mathrm{U} / 1(8-52 \mathrm{U} / \mathrm{l})$.

She continued to have recurrent episodes of abdominal pain. She was referred to the gastroenterology clinic in June 2010 and had more investigations. An oesophagogastroduodenoscopy with biopsy, serum amylase, lipase and liver function tests was normal. On imaging, comprising ultrasound and MRI, the spleen had enlarged to $19 \mathrm{~cm}$, but no other abnormalities such as hepatomegaly or lymphadenopathy were seen. Serum ACE continued to be high at $250 \mathrm{U} / \mathrm{l}$.

During one of her clinical consultations, she mentioned that she had been on holiday to the Dominican Republic in 2003 and recalled being bitten by an insect. Following this, she had felt ill for several months with episodes of abdominal pain associated with fever, diarrhoea, nose bleeds and some joint swelling. She was therefore referred to the infectious diseases clinic in January 2011. A screen for Epstein-Barr virus, cytomegalovirus, toxocariasis, leishmaniasis and schistosomiasis was negative. Repeat tests for rheumatoid factor, anticyclic citrullinated peptide antibodies, antinuclear antibody, erythrocyte sedimentation rate and $\mathrm{C}$-reactive protein were within the normal range.

At this time she reported some mild joint swelling and discomfort affecting her fingers. A rheumatology opinion was sought with a provisional diagnosis of sarcoid. However, given the persistently raised ACE level in association with splenomegaly over the years in an otherwise well young person, type I Gaucher's disease was thought to be likely. Plasma acid- $\beta$ glucosidase (GBA) was very low at $0.1 \mu \mathrm{mol} / \mathrm{g} . \mathrm{h} \quad(1-5 \mu \mathrm{mol} / \mathrm{g} . \mathrm{h})$, while plasma chitotriosidase levels were elevated at $16500 \mu \mathrm{mol} / \mathrm{l} . \mathrm{h}(4.0-120.0 \mu \mathrm{mol} / \mathrm{l} / \mathrm{h})$. X-ray of the lower end of femur showed flaring, described as 'Erlenmeyer flask deformity' (figure 1).

She was referred to the Lysosomal Disorders Unit at Addenbrooke's Hospital, Cambridge, where repeat enzyme levels confirmed a diagnosis of type I Gaucher's disease.

\section{INVESTIGATIONS}

- Serum $A C E=250 \mathrm{U} / \mathrm{l}(8-52 \mathrm{U} / \mathrm{l})$

- Plasma GBA=0.1 $\mu \mathrm{mol} / \mathrm{g} . \mathrm{h}(1.0-5.0 \mu \mathrm{mol} / \mathrm{g} . \mathrm{h})$

- Plasma chitotriosidase levels $=16500 \mu \mathrm{mol} / \mathrm{l} . \mathrm{h}$ (4.0-120.0 $\mu \mathrm{mol} / \mathrm{l} / \mathrm{h})$

- Abdominal ultrasound scan=splenomegaly

- X-ray of the lower femur=Erlenmeyer flask deformity 


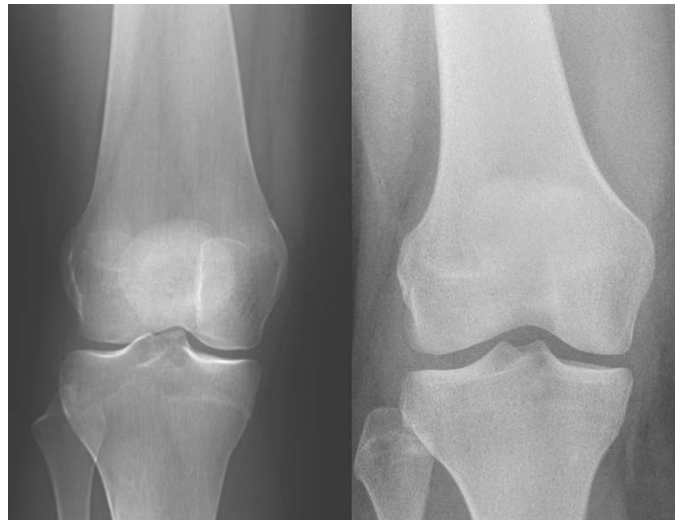

Figure $1 \mathrm{X}$-ray of the distal femur in the patient (left) and an age matched control (right) illustrating Erlenmeyer flask deformity.

\section{DIFFERENTIAL DIAGNOSIS}

Differential diagnosis of paediatric splenomegaly includes myriad causes: haematological, infectious and metabolic storage disorders that may manifest with an enlarged spleen. In this case, investigations for hereditary spherocytosis, autoimmune haemolytic anaemia, porphyria and haemoglobinopathies were all negative apart from mild thrombocytopenia, which is not uncommon in subjects with splenomegaly. The history of insect bite on her previous holiday to the Dominican Republic prompted a screen for Epstein-Barr virus, cytomegalovirus, toxocariasis, leishmaniasis and schistosomiasis, which was negative.

However, when one considers the combination of splenomegaly and raised ACE levels, the list of potential aetiologies is narrowed down to only three conditions: Gaucher's disease, juvenile sarcoidosis and chronic granulomatous disease (CGD). ${ }^{2-4}$ Sarcoidosis, being the commonest disorder, was repeatedly thought to be culpable in this young girl. CGD is a $\mathrm{x}$-linked disorder and is primarily seen in men. Some female carriers can manifest the disease, but the phenotype of growth failure, abnormal wound healing, diarrhoea and infective dermatitis would not apply to this patient.

Despite the fairly narrow differential diagnosis, neither Gaucher's disease, nor CGD was considered in this patient until much later.

\section{TREATMENT}

Management of type I Gaucher's disease involves replacement of the deficient enzyme with a recombinant product. In the UK, this is imiglucerase (Cerezyme) or velaglucerase alpha (VPRIV), administered by intravenous infusion every 2 weeks for non-neuropathic manifestations in types I and III Gaucher's disease. ${ }^{5}$ The annual cost of replacement therapy for an adult is in the region of $£ 250000$. $^{6}$ For subjects who are unwilling or unable to receive enzyme replacement therapy, substrate reduction therapy with an oral drug called miglustat (Zavesca) is available. ${ }^{5}$ This works by decreasing the synthesis of glucocerebroside, the substrate of the deficient enzyme.

\section{OUTCOME AND FOLLOW-UP}

The patient is being followed up by the Lysosomal Storage Disorders Unit at Addenbrooke's Hospital in Cambridge. She is receiving regular enzyme replacement therapy (velaglucerase alpha) and is doing well. Her bone pain has improved, she has had no further episodes of abdominal pain or diarrhoea and she is attending college.

\section{DISCUSSION}

Gaucher's disease is caused by deficiency in the production of the lysosomal enzyme glucocerebrosidase, also known as GBA, with autosomal recessive inheritance. As a result, the glycolipid glucocerebroside accumulates in macrophages in different parts of the body such as liver, bone marrow, spleen and nervous system. $^{7}$ Gaucher's disease has two major phenotypes, nonneuropathic (type I) and neuropathic (types II and III). ${ }^{8}$

Type I, the most common form of Gaucher's disease, has a high prevalence in the Ashkenazi Jewish population at $1: 1000{ }^{9}$ Children or adolescents with this disease may be asymptomatic or may present with hepatosplenomegaly, anaemia and thrombocytopaenia. Furthermore, they can have features of skeletal infiltration including osteopaenia, pathological fractures, bone necrosis and deformities. ${ }^{10} \mathrm{~A}$ characteristic radiological finding of this condition is flaring of the lower end of the femur, described as Erlenmeyer flask deformity. ${ }^{11}$ In addition, involvement of other organs such as the gastrointestinal tract has been reported in the literature. The nervous system is not involved in type I Gaucher's disease, which accounts for the relatively benign phenotype.

Type II is a part of neuropathic phenotype and is characterised by rapidly progressive neurological disease as well as severe visceral involvement. Children with this type of Gaucher's disease usually die in the first 2-3 years of life. Neurological manifestations in patients with type III Gaucher's disease appear later in life and include ataxia, seizures and abnormal eye movements. ${ }^{12}$ The pace of deterioration is slower than in type II disease, but types II and III can be difficult to distinguish.

Gaucher's disease is diagnosed by enzymatic analysis to determine the activity of GBA in peripheral blood leucocytes or fibroblasts. Biomarkers of alternative macrophage activation such as chitotriosidase activity and plasma CCL-18 are also helpful in corroborating the diagnosis of Gaucher's disease. ${ }^{13}$ Elevated levels of ACE, while non-specific, can be an early pointer to the diagnosis, as in this patient. ${ }^{14}$

ACE is present in the endothelium of pulmonary and renal blood vessels as well as in cells derived from the monocytemacrophage system. ${ }^{15}$ It is also found in the small intestine and choroid plexus. ${ }^{16}$ Raised serum ACE has been reported in granulomatous and non-granulomatous disorders. Examples of the first group include sarcoidosis, silicosis, asbestosis and Gaucher's disease. The enzyme can also be raised in certain non-granuloma-forming conditions, namely hyperthyroidism and cholestasis. ${ }^{15}$

Genetic testing following appropriate counselling will identify possible carriers linked to the index case. ${ }^{11}$

\section{Learning points}

- Elevated serum ACE level does not always equate with sarcoidosis.

- Hepatosplenomegaly in a young subject should make the clinician suspicious of lysosomal storage diseases.

- Bone deformity (Erlenmeyer flask deformity) is a characteristic radiological finding of Gaucher's disease.

Competing interests None.

Patient consent Obtained.

Provenance and peer review Not commissioned; externally peer reviewed. 


\section{REFERENCES}

1 Connock M, Burls A, Frew E, et al. The clinical effectiveness and cost-effectiveness of enzyme replacement therapy for Gaucher's disease: a systematic review. Health Technol Assess 2006;10:3-136.

2 Balameena S, Santh Ledge G, Panchapakesa Rajendran C, et al. Childhood Sarcoidosis 2004;6:4.

3 Mclean-Tooke1 APC, Aldridge C, Gilmour K, et al. An unusual cause of granulomatous disease. BMC Clin Pathol 2007;7:1.

4 Elstein D, Abrahamov A, Hadas-Halpern I, et al. Gaucher's disease. Lancet 2001;358:324-7.

5 Deegan P, Hughes D, Mehta A, et al. UK National Guideline for Adult Gaucher Disease. Department of Health National Specialist Commissioning Advisory Group, 2005.

6 Joint Formulary Committee. British National Formulary (online). London: BMJ Group and Pharmaceutical Press. http://www.medicinescomplete.com

7 Beutler E. Gaucher disease: multiple lessons from a single gene disorder. Acta Paediatr Supp/ 2006;95:103-9.

8 Kaplan P, Baris H, De Meirleir L, et al. Revised recommendations for the management of Gaucher disease in children. Eur J Pediatr 2012 (Epub ahead of print).
9 Balwani M, Fuerstman L, Kornreich R, et al. Type 1 Gaucher disease: significant disease manifestations in "asymptomatic" homozygotes identified by prenatal carrier screening. Arch Intern Med 2010;170:1463-9.

10 Zimran A. Gaucher's disease. Cambridge: Balliere Tindall, 1997.

11 Chen M, Wang J. Gaucher disease: review of the literature. Arch Pathol Lab Med 2008;132:851-3.

12 Erikson A, Bembi B, Schiffmann R. Gaucher's disease. London: Bailliere Tindall, 1997.

13 Giraldo P. Guidelines for type 1 Gaucher's disease. Med Clin (Barc) 2011;137:55-60.

14 Silverstein E, Friedland J. Elevated serum and spleen angiotensin converting enzyme and serum lysozyme in Gaucher's disease. Clin Chim Acta 1977;74:21-5.

15 Bénéteau-Burnat B, Baudin B. Angiotensin-converting enzyme: clinical applications and laboratory investigations on serum and other biological fluids. Crit Rev Clin Lab Sci 1991;28:337-56.

16 Lauta VM. ACE: physiopathology and role in the diagnosis and prognosis of systemic granulomatosis, neoplasms and lung toxicity caused by antineoplastic agents. Recenti Prog Med 1990;81:601-13.

Copyright 2013 BMJ Publishing Group. All rights reserved. For permission to reuse any of this content visit http://group.bmj.com/group/rights-licensing/permissions.

BMJ Case Report Fellows may re-use this article for personal use and teaching without any further permission.

Become a Fellow of BMJ Case Reports today and you can:

- Submit as many cases as you like

- Enjoy fast sympathetic peer review and rapid publication of accepted articles

- Access all the published articles

- Re-use any of the published material for personal use and teaching without further permission

For information on Institutional Fellowships contact consortiasales@bmjgroup.com

Visit casereports.bmj.com for more articles like this and to become a Fellow 